\title{
MEKANISME PEMBERIAN INSENTIF TENAGA AKADEMIK DI UNIVERSITAS NEGERI YOGYAKARTA
}

\author{
1)Hani'atul Milah, 2)Udik Budi Wibowo \\ 1, 2)Fakultas Ilmu Pendidikan Universitas Negeri Yogyakarta \\ 1)hanimilah@gmail.com, 2)yube2u@yahoo.com
}

\begin{abstract}
Abstrak
Penelitian ini mengkaji tentang mekanisme pemberian insentif dan dampaknya terhadap kinerja tenaga akademik di UNY. Dampak insentif ini dilihat secara umum dan pascalahirnya kebijakan baru tentang penghentian beberapa insentif finansial dosen tahun 2013. Penelitian ini menggunakan metode kualitatif, pengumpulan data melalui wawancara mendalam, observasi dan studi dokumentasi, dengan sampel purposive dan teknik snowball. Pembahasan hasil penelitian dilakukan dengan analisis induktif interpretatif komponensial yang dikembangkan berdasarkan model Spradley. Hasil penelitian menunjukkan bahwa, (1) UNY tidak memiliki satu aturan khusus dan integral yang mengatur mekanisme pemberian insentif untuk tenaga akademik, baik pada tingkat universitas maupun fakultas. (2) Insentif finansial, non-finansial dan perverse incentives yang ditemukan dari hasil penelitian memiliki pengaruh terhadap kinerja tenaga akademik. Tetapi insentif finansial memiliki pengaruh lebih signifikan dibanding kedua bentuk insentif lain. Hal ini ditunjukkan dengan tingkat kehadiran dosen mengajar dan mengawas ujian mahasiswa di kelas yang tinggi saat ada insentif dan menurun saat insentif tersebut dihilangkan.
\end{abstract}

Kata kunci: insentif, dampak insentif, tenaga akademik

\section{THE MECHANISM OF INCENTIVE DISTRIBUTION OF ACADEMIC STAFF AT YOGYAKARTA STATE UNIVERSITY}

\author{
1)Hani'atul Milah, 2)Udik Budi Wibowo \\ 1, 2)Fakultas Ilmu Pendidikan Universitas Negeri Yogyakarta \\ 1)hanimilah@gmail.com, 2)yube2u@yahoo.com
}

\begin{abstract}
This study reveals the mechanism of incentive distribution and its impact on the performance of academic staff at UNY. Its impact is seen in general and after the issuing of a new policy that stopped the financial incentives of lecturer in 2013. The research used a qualitative method. Data were collected through depth interview, observation, and review of documents, with purposive sampling based on snowball technique. The data was analyzed using componential interpretative inductive analysis developed by Spradley' model. The result shows, (1) UNY does not have the specific and integral rules that regulate mechanism of incentive distribution for academic staff, both at the university and faculty level. (2) Financial, non-financial and perverse incentives found from the research have an influence on the performance of academic staff, but financial incentive has more significant effect than the two other incentives forms. It is shown by the lecturers presence for teaching and supervising students examination in the class which is high when there is a financial incentives and decreases when there was no financial incentives.

Keywords: Incentive, the impact of incentives, academic staff
\end{abstract}




\section{Pendahuluan}

Dosen merupakan salah satu komponen esensial dalam suatu sistem perguruan tinggi. Peran, tugas, dan tanggung jawab dosen sangat bermakna untuk andil dalam mencerdaskan calon lulusan perguruan tinggi nantinya. Dosen juga dituntut untuk dapat memperlihatkan kinerja yang baik. Peningkatan kinerja dosen ini memerlukan beberapa hal seperti motivasi yang tinggi, kompetensi yang memadai, kepemimpinan yang baik, dan lingkungan kerja yang mendukung (Pramudyo, 2010, pp. 1-2).

Lembaga pendidikan tinggi sebagai penyedia jasa tentunya telah memikirkan imbalan yang sepadan -sebagai motivator kerja- bagi dosen yang merupakan "pekerja" yang memiliki tingkat pendidikan yang tinggi dan pengalaman mengikuti pelatihan yang banyak. Dalam konteks ini, tentu dosen memiliki "posisi tawar" yang tinggi di hadapan lembaga. Hal ini seperti yang dinyatakan oleh Siagian (2002, p. 98) bahwa semakin tinggi tingkat pendidikan dan makin banyak jenis pelatihan yang pernah diikuti oleh seseorang, maka "posisi tawar" (bargaining position) akan semakin kuat. Posisi tawar yang kuat memungkinkan seseorang untuk mendapatkan imbalan yang menarik dari tempat di mana dia bekerja. Imbalan ini tidak hanya berupa gaji dan tunjangan yang tinggi tapi juga bentuk-bentuk insentif lainnya.

Universitas Negeri Yogyakarta (UNY) termasuk salah satu lembaga pendidikan yang sejak lama memberikan berbagai insentif. Stajkovic \& Luthans secara garis besar, membagi jenis insentif menjadi dua macam, yakni insentif material (finansial) dan insentif non-material. Insentif material dalam organisasi juga biasa disebut sebagai insentif moneter. Karakteristik umum insentif moneter ini pembiayaannya berasal langsung dari sumber keuangan organisasi, yang diberikan secara langsung kepada karyawan yang berprestasi dalam bentuk uang, jaminan sosial atau barang berharga. Kedua, insentif non-material. Insentif jenis ini adalah pemberian penghargaan (reward) organisasi kepada karyawan yang berprestasi di luar ketentuan gaji pokok berupa uang dan insentif material. Bentuknya adalah seperti pengakuan sosial dan umpan balik kinerja (performance feedback) (Stajkovic \& Luthans, 2001, pp. 581-583).

Demikian juga UNY, telah memberikan insentif dalam dua bentuk, yaitu insentif finansial maupun insentif nonfinansial sebagai faktor pendorong atau motivator untuk meningkatkan kinerja dari tenaga akademik (dosen) yang dimilikinya. Dimana Menurut penulis, langkah yang diambil UNY ini penting, karena di satu sisi dapat dilihat sebagai upaya untuk menjembatani kesenjangan antara dosen yang memiliki pendorong motivasi intrinsik saja dan yang memiliki pendorong motivasi ekstrinsik saja. Sedangkan di sisi lain, adanya insentif yang memberikan nilai tambah terhadap peningkatan kinerja dosen secara otomatis juga dapat membantu dalam menjadikan perguruan tinggi lebih bermutu.

Pemberian insentif tersebut masih banyak menyisakan berbagai masalah khususnya terkait dengan sistem pengelolaannya. Permasalahan-permasalahan ini dapat dilihat dari: adanya perbedaan jumlah insentif yang diberikan kepada dosen dari tiap-tiap fakultas, perbedaan pemberian insentif antardosen ini telah mengakibatkan sebagian dosen merasa diperlakukan kurang adil, dan pemberian insentif ini juga acap kali tidak tepat waktu (terlambat). Selain itu, meskipun ada insentif mengajar, dari hasil evaluasi kehadiran pada akhir perkuliahan masih ada beberapa dosen yang melaksanakan perkuliahan kurang dari 16 kali pertemuan seperti harapan tiap fakultas. Dengan memperhatikan berbagai permasalahan yang dihadapi UNY di atas, penulis berpendapat bahwa ada permasalahan mendasar terkait mekanisme pemberian insentif, khususnya jika melihat dampak insentif terhadap motivasi mengajar dosen di atas yang masih rendah.

Dari berbagai paparan yang telah disampaikan tersebut, penelitian ini bertujuan untuk mengkaji tentang mekanisme pemberian insentif dan dampaknya terhadap kinerja tenaga akademik di UNY. Dampak insentif ini dilihat secara umum 
dan pascalahirnya kebijakan baru tentang penghentian beberapa insentif finansial dosen tahun 2013.

\section{Metode Penelitian}

Metode yang digunakan dalam penelitian ini adalah metode kualitatif dengan rasional untuk mengeksplorasi dan memahami makna yang oleh sejumlah individu maupun kelompok dianggap berasal dari masalah sosial atau kemanusiaan (Creswell, 2009, p. 4).

Penelitian ini bermaksud untuk mencari kebenaran dan keberhasilan suatu mekanisme pemberian insentif dalam meningkatkan kinerja dari tenaga akademik di UNY. Berdasarkan data dan keadaan sesungguhnya tentang mekanisme pemberian insentif finansial maupun non-finansial, dan kinerja pada saat mendapatkan insentif dan pada saat insentif tersebut dihilangkan. Penelitian ini tidak dimaksudkan untuk melakukan generalisasi terhadap temuan atau pengujian hipotesis, dan tidak menguji kebenaran antarvariabel, akan tetapi lebih menekankan pada pengumpulan data untuk mendeskripsikan keadaan yang terjadi sesungguhnya.

Penelitian ini dilakukan di Universitas Negeri Yogyakarta yang terdiri dari tujuh fakultas, akan tetapi, dalam penelitian ini hanya di pilih tiga fakultas, yaitu Faklutas Ilmu Pendidikan (FIP), Fakultas Bahasa dan Seni (FBS), dan Fakultas Ekonomi (FE). Pemilihan ketiga fakultas ini didasarkan atas dua argumen berikut: perta$m a$, adalah terkait dengan keterbatasan waktu dan tenaga yang dimiliki oleh peneliti. Kedua, ketiga fakultas ini, berdasarkan penilaian peneliti memiliki karakteristik unik yang setidaknya dapat mewakili keberagaman dari karakter dan budaya di tiap-tiap fakultas yang ada di UNY. FIP disini memiliki umur yang lebih tua dibanding fakultas lainnya, sehingga memiliki kultur yang cenderung masih mengikuti pada budaya-budaya lama yang diwarisi oleh IKIP, yakni prosedural, normatif dan birokratis. Ini tentu berbeda dengan FBS, sebagai fakultas yang dihuni oleh banyak sarjana-sarjana seni, memiliki karak- ter, watak dan budaya yang cukup lentur dan sedikit bebas, sehingga memiliki kecenderungan tidak birokratis dan anti penyeragaman. Sedangkan FE, adalah termasuk fakultas yang termuda di UNY. Sebagai fakultas termuda, FE memiliki budaya dan semangat kerja yang tinggi untuk mengejar ketertinggalanya atas fakultas-fakultas yang lebih dulu lahir.

Penelitian ini dilakukan mulai mulai bulan November 2013 sampai dengan bulan Maret 2014. Objek penelitian ini adalah informasi mengenai mekanisme pemberian insentif tenaga akademik di UNY serta dampak dari mekanisme pemberian insentif tersebut dalam meningkatkan kinerja. Untuk mendapatkan informasi berdasarkan maksud dan tujuan penelitian, maka peneliti perlu menentukan subjek penelitian, yaitu orang-orang yang dianggap paling mengetahui permasalahan yang digali dan terlibat aktif dalam kegiatan mekanisme pemberian insentif.

Dalam menentukan subjek penelitian dilakukan dengan menggunakan metode purposive sampling dan snowball sampling. Subjek peneliti di sini selanjutnya disebut sebagai key informant. Dalam penelitian ini, peneliti menentukan informan utama, yaitu Wakil Rektor II, Kabiro Umum, Perencanaan, Keuangan, dan dosen, Wakil Dekan II. Sementara informan sekunder adalah: dekan, wakil dekan I dan III, dan karyawan.

Dosen yang dijadikan sebagai subjek penelitian dalam studi ini tidak diklasifikasikan berdasarkan tingkat usia ataupun tingkat kesejahteraan (dosen yang mendapatkan sertifikasi dan tidak mendapatkan sertifikasi) sebagaimana yang dilakukan dalam penelitian kuantitatif. Akan tetapi, dalam penelitian ini, penulis memberikan batasan subjek penelitian, yaitu hanya pada jajaran yang tidak memiliki jabatan struktural baik ditingkat jurusan, fakultas, maupun di tingkat rektorat. Artinya, dampak insentif yang akan dicoba dieksplanasi dalam penelitian ini adalah tidak pada semua katagori dosen, tapi hanya pada mereka (dosen) yang tidak memiliki jabatan struktural saja. Karenanya pun, mereka pa- 
ra dosen juga dijadikan salah satu key informant (informan kunci) dalam penelitian ini.

Data dikumpulkan melaui: wawancara mendalam, observasi/pengamatan langsung, dan (3) kaji dokumentasi. Instrumen yang digunakan dalam penelitian ini adalah pedoman wawancara mendalam. Pedoman wawancara terdiri dari pedoman wawancara untuk key informan, yaitu pejabat yang terlibat langsung dalam penyusunan kebijakan mekanisme pemberian insentif. Selain untuk key informan, peneliti juga menyiapkan pedoman wawancara untuk tenaga akademik. Pedoman wawancara untuk tenaga akademik digunakan untuk mengkonfirmasi dari wawancara dengan key informan.

Analisis data penelitian adalah bagian dari proses menjawab pertanyaan penelitian. Dalam konteks studi ini, analisis data tentang mekanisme pemberian insentif terhadap kinerja tenaga akademik di UNY dilakukan secara terus menerus dimulai sejak awal penelitian dilakukan hingga akhir penelitian dan penulisan hasil penelitian. Data penelitian kualitatif ten- tang tema penelitian yang dihasilkan tersebut diolah dengan menggunakan analisis induktif interpretative.

Adapun proses dalam melakukan analisis induksi (analysis induction) ini dilakukan dengan mengacu model yang $\mathrm{d}$ ikembangkan oleh Spradley (dalam Sugiyono, 2012, pp. 99-116), yaitu analisis domain, analisis taksonomi, analisis komponensial, dan analisis tema.

Dari keempat analisis tersebut, peneliti menggunakan model analisis komponensial, yaitu proses untuk menguji konsep-konsep dan/atau teori-teori dasar tentang mekanisme pemberian insentif dan dampaknya terhadap kinerja tenaga akademik di UNY yang telah didapatkan dari hasil penggalian data sebelumnya. Proses ini dilakukan untuk tidak hanya mencari persamaan pengetahuan tentang masalah penelitian dari sumber informasi, tapi lebih dari itu yakni mencari data yang memiliki perbedaan atau yang kontras. Proses ini dilakukan dengan triangulasi data melalui observasi, wawancara, dan dokumentasi yang terseleksi.

\section{Hasil Penelitian dan Pembahasan}

Tabel 1. Resume Temuan Penelitian tentang Mekanisme, Macam-Macam dan Tujuan Pemberian Insentif

\begin{tabular}{|c|c|c|}
\hline No & $\begin{array}{l}\text { Subbab } \\
\text { Pembahasan }\end{array}$ & Temuan Penelitian \\
\hline 1. & $\begin{array}{l}\text { Mekanisme } \\
\text { Pemberian } \\
\text { Insentif }\end{array}$ & $\begin{array}{l}\text { (a) UNY tidak memiliki kebijakan yang secara khusus mengatur satu paket mekanisme } \\
\text { pemberian insentif untuk dosen, baik insentif finansial maupun insentif non-finansial dan } \\
\text { insentif jenis lainnya. } \\
\text { (b) Pada tingkat universitas, insentif finansial untuk dosen di UNY hanya diatur dalam satu } \\
\text { paket kebijakan universitas berbentuk peraturan rektor tentang Standar Umum } \\
\text { Pembiayaan Universitas yang dilakukan perubahan setiap tahunnya disesuaikan dengan } \\
\text { anggaran dan kebutuhan universitas. } \\
\text { (c) Pada tingkat fakultas, dimana juga tidak memiliki kebijakan khusus yang mengatur } \\
\text { mekanisme insentif untuk dosen. Insenti finansial yang diberikan pihak fakultas ke dosen } \\
\text { hanya dibuat berdasarkan SK yang sifatnya tertentu, termasuk insentif non-finansial dan } \\
\text { perverse incentives (insentif hukuman) yang ada di UNY. }\end{array}$ \\
\hline 2. & $\begin{array}{l}\text { Macam- } \\
\text { Macam } \\
\text { Insentif }\end{array}$ & $\begin{array}{l}\text { Berdasarkan data yang dikumpulkan, ditemukan } 3 \text { macam insentif yang diperoleh dosen di } \\
\text { lingkungan UNY, diantaranya: } \\
\text { (a) Insentif finansial [direct dan indirect]; } \\
\text { (b) Insentif non-finansial; } \\
\text { (c) Insentif yang bersifat negative atau hukuman [perverse incentives]. }\end{array}$ \\
\hline 3. & $\begin{array}{l}\text { Tujuan } \\
\text { Insentif }\end{array}$ & $\begin{array}{l}\text { (a) Memberikan tambahan kesejahteraan seorang dosen, khususnya terkait dengan insentif } \\
\text { finansial; dan } \\
\text { (b) Memberikan stimulus agar para dosen lebih memiliki kedisiplinan, tanggungjawab/ko- } \\
\text { mitmen, motivasi yang tinggi dan lebih produktif dalam menjalankan profesinya sebagai } \\
\text { dosen yang memiliki tugas sebagaimana termanifes dalam tri darma perguruan tinggi. }\end{array}$ \\
\hline
\end{tabular}

Sumber: diolah dari hasil wawancara 
Tabel 2. Resume Temuan Penelitian tentang Perubahan Kebijakan Insentif dan Pengaruh Insentif terhadap Kinerja Dosen

No Sub Bab Pembahasan Temuan Penelitian

1. Perubahan Kebijakan Perubahan kebijakan pemberian insentif di UNY dimulai sejak tahun 2013. Pemberian Insentif Beberapa insentif tersebut adalah insentif mengajar, insentif membuat soal, insentif mengawas ujian, dan insentif mengoreksi ujian

2. a. Awal dan Sejarah

Pemberhentian

(a) Inisiatif para pengambil kebijakan dengan mempertimbangkan kondisi fiskal universitas (antisipasi pemberlakuan sistem uang kuliah tunggal yang Beberapa Insentif berakibat pada devisitnya anggaran yang berasal dari universitas); dan

(b) Mengembalikan pada tupoksi dosen yang sesungguhnya (back on the right track).

b. Dinamika dan

Respon atas

Kebijakan

Pemberhentian Insentif

(a) Umumnya, para pejabat dekanat memahami dan memaklumi atas hadirnya kebijakan insentif yang baru, sehingga mereka tidak mengeluarkan protes pada pihak universitas. Hal ini disebabkan tiga alasan, yakni: (1) anggaran universitas yang semakin berkurang akibat adanya UKT (uang kuliah tunggal);

(2) tunjangan sertifikasi dosen (serdos) dilihat sudah meng-cover dan mensubtitusi insentif-insentif atas kinerja dosen; (3) mengembalikan pada tupoksi dosen.

(b) Sedangkan ditataran para dosen, umumnya mereka menganggap kebijakan tersebut bagian dari penurunan kesejahteraan, terlebih bagi dosen yang belum mendapatkan serdos. Hal ini yang membuat sebagian dari mereka menyampaikan protes kepada pengambil kebijakan baik ditingkat fakultas maupun universitas.

3. Pengaruh Insentif terhadap Kinerja Dosen

a) Insentif baik finansial maupun non-finansial memiliki pengaruh terhadap kinerja dosen. Tetapi, insentif finansial memiliki pengaruh positif sebagai motivator terhadap kinerja dosen, khususnya yang belum mendapatkan serdos. Karena insentif finansial dirasa penting untuk membantu keuangan dosen, terlebih bagi dosen yang belum mendapatkan tunjangan serdos.

b) Dengan dihilangkannya beberapa insentif finansial mulai tahun 2013 sangat mempengaruhi kinerja dosen, yang tidak hanya bagi dosen yang belum tersertifikasi tapi juga bagi dosen yang sudah tersertifikasi. Hal ini terlihat dari menurunnya motivasi dosen untuk memenuhi tugas mereka dalam mengajar dan mengawas ujian. Rendahnya tingkat dosen yang mau mengajar lebih dari jumlah pertemuan yang ditentukan oleh tiap fakultas, dan rendahnya kehadiran dosen untuk mengawas langsung ujian mahasiswa.

Sumber: diolah dari hasil wawancara.

Kebijakan dan Mekanisme Pemberian Insentif di UNY

Dari hasil penelitian ditemukan bahwa sebagian besar kebijakan pemberian insentif di UNY memiliki kebijakan yang terpusat. UNY mengatur pemberian insentif yang sifatnya langsung. Kebijakan insentif yang sifatnya langsung ini sudah diatur oleh pihak universitas melalui peraturan Rektor UNY tentang Setandar Biaya Umum Universitas yang setiap tahun diperbaharui. Contoh, insentif dosen yang diberikan untuk (sepanjang) tahun 2012 telah diatur sekaligus dalam Peraturan Rektor No. 1 Tahun 2012 Tanggal 2 Januari 2012 tentang Standar Biaya Umum Universitas (BUPK UNY, 2012). Peraturan Rektor
UNY tentang Standar Biaya Umum Universitas ini pasti akan diperbaharui kembali untuk tahun 2014 yang mana menyesuaikan dengan kebutuhan dan anggaran yang dimiliki universitas.

Penuangan macam-macam insentif ke dalam satu paket kebijakan standar biaya umum universitas tersebut, menunjukkan bahwa UNY belum memiliki satu kebijakan khusus yang mengatur mekanisme insentif baik untuk dosen maupun karyawan. Sehingga jenis dan jumlah nominalnya -insentif finansial- tidak memiliki perbedaan yang signifikan. Setiap fakultas memiliki variasi yang hampir sama. Artinya pada pelaksanaanya pun secara simetris tentu antarfakultas sama, bahkan dari segi jumlah nominal insentif yang diberi- 
kan. Hal ini dikarenakan pedoman acuan yang digunakan mengacu pada peraturan universitas yang telah ditetapkan oleh Rektor UNY yang berlaku untuk semua fakultas. Pertimbangan UNY menyatukan kebijakan insentif tersebut ke dalam standar biaya umum karena dipengaruhi oleh kemampuan dan/atau ketersediaan anggaran yang ada.

Faktor anggaran tersebut, yang kemudian membuat UNY tidak menempatkan insentif sebagai sebuah kebijakan yang memiliki makna 'wajib', atau dengan makna lain insentif adalah hal yang berada pada prioritas kedua (second priority) untuk diberikan pada dosen. Konsekuensinya, UNY dapat menaikkan, menurunkan, dan bahkan menghilangkan insentif-insentif untuk dosen. Artinya, ketika universitas memiliki anggaran yang cukup besar dan memungkinkan untuk memberi dan menaikkan insentif, maka universitas akan mengalokasikan anggaran tersebut untuk insentif dosen. Sebaliknya, apabila universitas mengalami devisit anggaran, maka sangat tidak menutup kemungkinan pihak pengambil kebijakan universitas akan mengurangi dan jika diperlukan menghilangkan alokasi anggaran untuk insentif dosen. Meskipun insentif itu (insentif finansial) merupakan komponen penting dalam sebuah organisasi untuk meningkatkan kinerja dan daya saing individu (tenaga akademik), dan juga lembaga (lihat Goodman \& Turner, 2010; Lazear, 2003; Levacic, 2009).

Kebijakan insentif dosen yang tercantum ke dalam standar biaya umum tersebut, dari hasil penelitian, ditemukan bahwa secara administratif memiliki mekanisme pendistribusian yang bersifat bottom up yang diawali dari pengajuan pihak fakultas ke pihak rektorat berdasarkan ketentuanketentuan yang termuat dalam peraturan Rektor tentang Setandar Biaya Umum Universitas tersebut. Sebagai contoh mekanisme pemberian insentif uang kehadiran dosen, dimana setiap fakultas akan membuat rekap kehadiran semua dosen berdasarkan presensi online yang mereka lakukan. Kemudian dari rekap presensi online tersebut, pihak fakultas akan mem- buat laporan secara tertulis yang diajukan ke pihak rektorat dalam bentuk SK (Surat Keterangan) tentang insentif kehadiran dosen di kampus. Setelah melalui mekanisme ini, maka uang/insentif kehadiran tersebut lasung bisa didistribusikan ke setiap dosen berdasarkan kinerja/kehadiran mereka masing-masing.

Contoh mekanisme pemberian insentif finansial, non-finansial, dan perverse incentives di UNY disajikan pada Gambar 1, 2, dan 3.

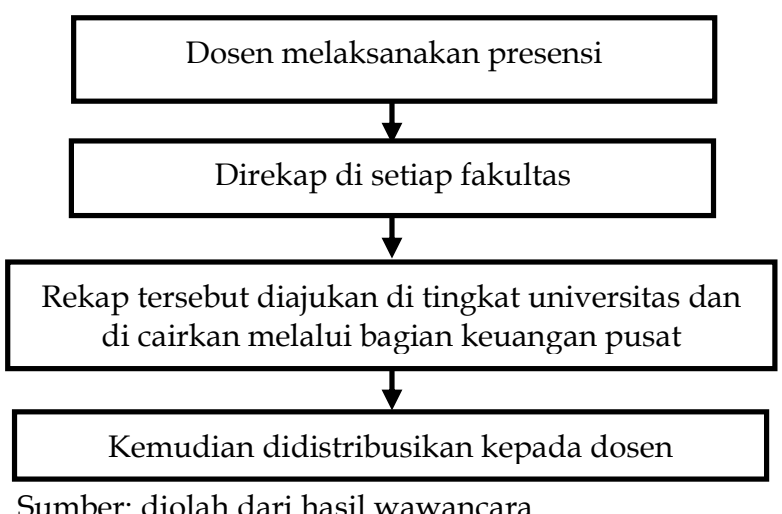

\section{Gambar 1. Mekanisme Insentif Finansial di UNY}

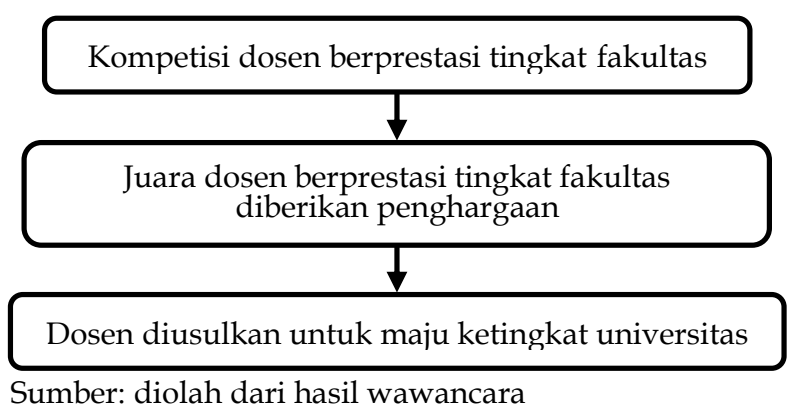

Gambar 2. Mekanisme Insentif Nonfinansial di UNY

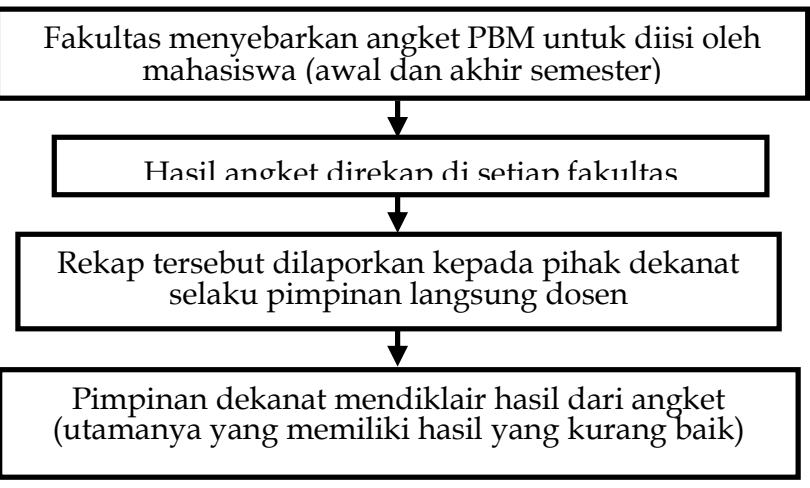

Sumber: diolah dari hasil wawancara

Gambar 3. Mekanisme Insentif Bentuk Perverse Incentives di UNY 


\section{Macam-Macam Insentif}

UNY sebagai lembaga pendidikan tinggi, telah memberikan beberapa insentif untuk memacu dan meningkatkan tingkat kualitas kerja para dosennya. Setidaknya, secara garis besar, penelitian ini menemukan tiga jenis insentif yang diperoleh seorang dosen yang mengajar di UNY. Pertama, insentif finansial (monetary incentives) atau uang kesejahteraan; kedua, insentif non-finansial (non-monetary incentives); dan ketiga, insentif dalam bentuk punishment (hukuman/teguran), atau biasa juga disebut sebagai perverse incentives.

\section{Insentif Finansial}

Insentif dalam bentuk finansial -uang atau barang yang memiliki nilai kesejahteraan materian- yang diperoleh para dosen di UNY bukanlah dalam bentuk tunggal, jika dilihat berdasarkan sifat, jenis barang/jasa (beneficial) dan proses pemberiannya. Mengacu pada konsenptual Chapman dan Miric (2009, p. 323), sebagaimana disinggung di atas, penulis menemukan dua bentuk insentif untuk dosen, yakni insentif langsung (direct incentives) dan insentif tidak langsung (indirect incentives).

Pertama, insentif finansial langsung (direct monetary incentives) dalam studi ini dipahami sebagai keuntungan (benefit) yang didapatkan seorang tenaga pendidik (baca: dosen) untuk pembayaran atas jerih payahnya dalam bekerja, yang meliputi gaji (salaries), tunjangan (allowances) dan keuntungan-keuntungan kecil (fringe benefits) lain (bandingkan dengan Chapman \& Miric, 2009, p. 323). Jika secara konseptual Chapman dan Miric memberikan cakupan direct monetary incentives dengan tidak saja memasukkan tunjangan dosen, keuntungan-keuntungan material sampingan (fringe material benefits) -dalam konteks insentif di UNY, seperti uang menguji tugas akhir mahasiswa dan memberi bimbingan mahasiswa- tapi juga memasukkan gaji (salaries/ main wage) sebagai direct incentif, maka dalam studi ini gaji pokok (main wage) tidak penulis masukkan sebagai bagian dari insentif. Hal ini dikarenakan dalam kerangka teoritik/konseptual insentif yang digunakan sebagai kerangka analisis dalam penelitian ini dipahami sebagai keuntungan (benefit) atau tunjangan yang diberikan pada dosen oleh lembaga diluar gaji pokok.

Adapun bentuk-bentuk direct incentives yang didapatkan seorang dosen di UNY, umumnya, bersifat akademik. Dengan kata lain, insentif yang didapatkan sebagai imbalan kerja seorang dosen dalam mengembangkan lembaga, mendidik dan melayani mahasiswa yang berkaitan dengan tugasnya sebagai seorang dosen. Bentuk insentif-insentif ini telah diatur secara universal oleh pihak universitas, baik berdasarkan kebijakan yang dibuat oleh internal pembuat kebijakan (policy maker) universitas (pejabat rektorat) maupun turunan dari pemerintah pusat (kemendikbud).

Kedua, insentif tidak langsung (indirect incentives) dalam studi ini dapat dipahami sebagai sesuatu (goods or benefit) yang diberikan untuk memperbaiki/meningkatkan kondisi kerja (working lives) dan kapasitas diri seorang dosen (self capacity). Insentif jenis ini adalah meliputi dana-dana pembinaan, pelayanan atas kebutuhan hidup dan pengembangan kapasitas dosen (baca Chapman \& Miric, 2009, p. 323). Berbeda halnya dengan direct incentives, dari hasil penelitian ditemukan bahwa insentif dalam kategori indirect incentives bagi dosen di UNY tersebut, memiliki dua mekanisme yang berbeda, yakni yang diatur langsung oleh universitas dan berlaku untuk semua fakultas dan dosen di dalamnya, dan insentif yang diatur tersendiri oleh pihak fakultas. Dan umumnya, insentif yang diatur dan diberikan oleh fakultasfakultas di UNY di luar insentif tidak langsung yang telah diberikan oleh pihak universitas di atas, cukup bervariatif bentuknya. Dengan kata lain, insentif finansial kategori indirect yang diberikan oleh satu fakultas tertentu terhadap seorang dosen di UNY belum tentu (dan mungkin tidak) diberikan oleh fakultas lain. Hal ini dikarenakan selain dipengaruhi faktor anggaran dan kebutuhan yang berbeda-beda tiaptiap fakultas, tapi juga dipengaruhi oleh kehendak dari pengambil kebijakan fakul- 
tas dalam memberikan kesejahteraan para dosen dan mendorong tingkat kualitas kerja mereka agar lebih baik.

\section{Insentif Non-Finansial}

Analisis penulis dari hasil penelitian sebagaimana dipaparkan pada data emik di atas, telah diketahui bahwa dosen yang mengajar di UNY selain mendapatkan insentif finansial, mereka juga mendapatkan insentif yang dalam studi ini disebut sebagai non-finansial, atau dalam kajian ekonomi sering disebut sebagai non-monetary incentives. Sama halnya dengan insentif finansial, insentif non-finansial selain diberikan oleh pihak universitas untuk semua dosen yang ada di UNY, juga diberikan oleh pihak fakultas-fakultas untuk masingmasing dosen yang mengajar di dalamnya.

Insentif non-finansial dari pihak universitas memiliki karakteristik berupa penghargaan dan kesempatan/peluang dosen untuk mengembangkan kapasitas diri dan karir yang lebih tinggi. Insentif ini berlaku diberikan untuk semua dosen yang ada di UNY. Sebagai contoh, seperti penghargaan atas dosen berprestasi selain melalui pemberian piagam tapi juga diumumkan pada publik (dosen, karyawan dan mahasiswa) dalam acara resmi. Selain itu, juga memberikan kesempatan dan mendorong dosen untuk mengikuti seminar, konferensi dan menulis jurnal dalam sekala internasional. Meskipun diperuntukkan bagi semua dosen UNY, untuk dua contoh insentif tersebut, tapi tetap bagi mereka yang menghendaki dan berusaha mendapatkan yang dapat memperoleh insentifinsentif tersebut. Hal ini dikarenakan insentif-insentif tersebut diberikan dengan syarat, sehingga konsekuensinya, meskipun diberi kesempatan untuk semua dosen tapi tetap mereka yang menang dalam berkompetisi yang akan mendapatkan insentifinsentif tersebut.

\section{Insentif Negatif/Hukuman (Perverse Incentives)}

Dari hasil penelitian penulis menemukan bahwa seorang dosen di UNY selain mendapatkan insentif finansial dan non-finansial sebagaimana dijelaskan di atas, juga mendapatkan jenis insentif lain, yang dalam studi ini penulis sebut sebagai perverse incentives atau punishment incentives. Artinya, insentif tidak hanya memiliki makna positif atau menguntungkan seperti tunjangan berupa uang/barang (benefit) dan penghargaan (reward), tapi sebaliknya memiliki makna negatif berupa hukuman, koreksi dan teguran.

Perverse incentive atau punishment incentives ini sengaja penulis masukkan dalam kategori insentif, karena insentif merupakan hal yang berkaitan dengan mempengaruhi psikologis seorang pekerja. Perlakuan atasan atau pengambil kebijakan organisasi terhadap karyawan/pekerja dalamrangka memajukan suatu lembaga bukan hanya memberikan informasi, dorongan dan motivasi (insentif non-finansial) terhadap mereka, tapi juga memberikan insentif yang sifatnya negatif seperti teguran terhadap pekerja yang kurang disiplin atau tidak memenuhi tugasnya dengan baik, bahkan menurunkan jabatan pada posisi yang lebih rendah juga diperlukan (baca Siagian, 2004, p. 164). Berdasarkan hasil penelitian, insentif jenis ini juga penulis temukan di UNY, baik yang bersumber dari pihak universitas maupun fakultas dan jurusan.

\section{Tujuan Pemberian Insentif untuk Dosen}

Pemberian Insentif (finansial, nonfinansial dan perverse incentives) oleh pihak UNY kepada para dosen yang mengajar di dalamnya, secaara garis besar memiliki tiga tujuan utama. Pertama, memberikan tingkat kesejahteraan secara ekonomi bagi kehidupan dosen. Dalam konteks ini, tentu yang dimaksud adalah insentif finansial baik dalam kategori direct incentives maupun indirect incentives. Sebagaimana telah dipaparkan dalam data emik, insentif finansial ini memiliki pengaruh dalam hal memotivasi dan juga memiliki arti penting bagi dosen baik dalam peningkatan kesejahteraan maupun dalam membuat seorang dosen menjadi lebih komit dalam bekerja dan terhadap UNY, khusus bagi para dosen yang belum mendapatkan tunjangan sertifikasi. 
Tujuan pemberian insentif yang kedua adalah, guna memberikan setimulus atau rangsangan bagi para dosen untuk lebih memiliki kedisiplinan, tanggungjawab, komitmen dan produktivitas yang lebih baik dalam menjalankan profesinya sebagai seorang dosen yang memiliki tugas sebagaimana termanifes dalam tri darma perguruan tinggi. Untuk tujuan yang kedua ini, dari analisis penulis, menemukan bahwa semua jenis insentif (finansial, non-finansial dan perverse incentives) yang diberikan pada dosen memiliki dan mengandung tujuan yang ketiga ini.

Ketiga, pemberian insentif memiliki tujuan untuk memberikan dorongan dan motivasi bagi para dosen untuk lebih dapat membangun kapasitas keilmuan dan/atau mengaktualisasikan diri sebagai seorang akademisi yang lebih mumpuni dibidang keilmuannya. Dari hasil wawancara dengan narasumber, penulis berargumen bahwa jenis insentif non-finansial yang memungkinkan bekerja lebih dominan dalam mewujudkan tujuan pemberian insentif yang ketiga ini. Sebagai contoh, seperti yang dilakukan oleh para pimpinan fakultas A, dimana guna mendorong kepercayaan diri dan meningkatkan kapasitas akademik para dosen, para pejabat dekanat tidak hanya memberikan insentif bagi para dosen fakultas tersebut berupa kesempatan untuk mengikuti kursus-kursus dan seminar (nasional dan internasional), tapi juga mendorong mereka untuk dapat mengajar di kampus-kampus mitra yang ada diluar negeri guna pengembangan keilmuan dengan menimba pengalaman dan ilmu baru.

\section{Perubahan Kebijakan Insentif Dosen}

Pembahasan sebelumnya, penulis telah mengeksplorasi tentang mekanisme dan macam-macam insentif yang diberikan pihak UNY kepada para dosen yang mengajar di dalamnya. Pada bagian ini, penulis akan mengeksplor kebijakan baru universitas tentang insentif dosen. Dimana pada tahun 2013 UNY melalui Peraturan Rektor tentang Standar Biaya Universitas No. 1 Tanggal 2 Januari 2013, yang didalamnya termuat serangkaian insentif untuk dosen, telah menghentikan beberapa insentif finansial langsung (direct financial incentives) untuk dosen diantaranya, meliputi honorarium atau insentif untuk mengajar, membuat soal, mengawas ujian, dan mengoreksi hasil ujian.

Bagian ini cukup penting untuk dieskplorasi lebih dalam guna mengantarkan dan melihat sejauh mana insentif yang diberikan pada dosen, khususnya insentif finansial, berpengaruh terhadap diri seorang dosen dalam menjalankan tri darma perguruan tinggi, yang notabene adalah sebuah keharusan dan kewajiban mereka sebagai para akademisi kampus. Dengan dihilangkannya insentif finansial dalam kategori direct incentives tersebut, tentu dapat mengurangi jumlah gaji atau pendapatan yang diperoleh seorang dosen yang mengajar di UNY sebelumnya.

Penghilangan beberapa insentif finansial yang berakibat pada semakin berkurang dan rendahnya pendapatan ekonomi/kapital dosen tersebut, jika merujuk dari literatur yang ada, memungkinkan dapat berdampak pada kualitas kerja dosen selama di kampus. Pengalaman dari beberapa negara, seperti Amerika dan Chile misalnya, bahwa rendahnya gaji (termasuk insentif) yang diterima seorang tenaga pendidik, memungkinkan memiliki tiga dampak terhadap proses pembelajaran. Pertama, rendahnya pendapatan/gaji dapat berpengaruh terhadap usaha dan kualitas dari kinerja tenaga pendidik (dosen); kedua, gaji yang rendah dapat berdampak buruk terhadap kualitas pendidikan siswa (students); dan ketiga, rendahnya pendapatan tenaga akademik dapat menyebabkan tenaga pendidik untuk menjadi pengajar yang baik dan profesional dalam menjalankan tugasnya, karena mereka akan sibuk mencari pendapatan di luar kampus. Ketiga dampak buruk ini, yang kemudian dapat memproduksi inefisiensi yang signifikan dalam proses pendidikan dan berdampak negatif dalam pembelajaran siswa/mahasiswa (Mizala \& Romaguera, 2005, p. 103). 
Pengaruh Pemberian Insentif terhadap Kinerja Tenaga Akademik di UNY

Pengaruh pemberian insentif terhadap kinerja dosen di sini akan dijelaskan dalam dua bagian. Pertama, penulis menjelaskan pengaruh insentif secara umum baik insentif finansial, non-finansial, maupun perverse incentives yang ditemukan dalam penelitian. Kedua, penulis menjelaskan tentang pengaruh kebijakan penghentian insentif finansial (mengajar, membuat soal, mengawas ujian, dan mengoreksi ujian) yang dikeluarkan mulai tahun 2013 terhadap kinerja dosen.

\section{Pengaruh Insentif Secara Umum}

Dari hasil penelitian ditemukan bahwa insentif finansial, non-finansial, dan perverse insentives memiliki pengaruh terhadap kinerja dosen. Hal ini dikarenakan semua jenis insentif tersebut memiliki perannya masing-masing. Peran insentif finansial bagi para dosen adalah untuk menambah income penghasilan di setiap bulan. Insentif jenis ini tidak boleh diabaikan oleh para pengambil kebijakan. Seperti dari beberapa hasil penelitian menunjukkan bahwa kurangnya insentif terhadap tenaga akademik (guru dan dosen) di suatu negara membuat mereka (guru dan dosen) memilih pekerjaan lain yang lebih menjanjikan insentif yang lebih besar (Vegas \& Umansky, 2005, pp. 3-4). Selain alasan di atas, bagi dosen insentif finansial juga diperlukan untuk membuat dosen lebih memiliki komitmen terhadap universitas atau lebih mementingkan kamajuan universitas daripada mencari "proyek" diluar kampus.

Sedangkan insentif yang sifatnya non-finansial diperlukan untuk membuat para dosen termotivasi untuk berkarya, lebih disiplin dan lebih bertanggung jawab dalam menjalankan tugas-tugas dosen sebagaimana termaktub dalam tri dharma perguruan tinggi. Selain itu, insentif yang umumnya berbentuk dorongan ini juga membuat para dosen lebih memiliki produktivitas dalam menulis jurnal maupun makalah baik dalam skala nasional maupun internasional. Peran insentif non-finansial tersebut juga bertujuan agar dosen memiliki semangat untuk mewujudkan UNY menjadi universitas berskala internasional (world class university). Insentif nonfinansial ini selain memiliki tujuan di atas, juga memiliki pengaruh terhadap insentif finansial. Dengan dorongan yang diberikan universitas kepada dosen untuk berkarya, dosen juga diuntungkan dengan adanya kemudahan naik pangkat. Kenaikan pangkat inilah yang kemudian mempengaruhi kenaikan nominal insentif finansial.

Sementara itu, insentif yang berbentuk hukuman/perverse insentives yang ditemukan dalam penelitian ini juga mempengaruhi kedisiplinan, komitmen, dan produktivitas dosen. Perverse incentives yang berlaku di UNY ini dalam pandangan pihak pengambil kebijakan tidak dimaknai sebagai menghukum atau menghakimi seorang dosen, melainkan bagian dari upaya untuk meminimalisir kecenderungan-kecenderungan dari tindakan dosen yang negatif, dan sebaliknya memaksimalkan tindakan dosen yang positif. Meskipun insentif bentuk ini tidak ada mekanisme yang tertulis secara jelas, tetapi penting bagi universitas untuk diterapkan secara adil dan menyeluruh guna menghindari toleransi atas tindakan dosen yang tidak disiplin tugas. Misalnya, membiarkan para dosen untuk melaksanakan kegiatan di luar kampus yang melebihi waktu sehingga melalaikan kewajiban yang ada di internal kampus, membiarkan nilai mata kuliah masuk melebihi batas tanggal yang telah ditentukan, dan membiarkan dosen melaksanakan perkuliahan dengan jumlah pertemuan kurang dari 75 persen (12 sampai 14 kali pertemuan).

\section{Pengaruh Kebijakan Penghentian Insentif Dosen}

Pemaparan tentang pengaruh insentif terhadap dosen di atas cukup jelas memberikan pengetahuan secara baik bagaimana ketiga bentuk insentif yang diberikan di UNY cukup penting untuk memberikan motivasi kepada dosen agar lebih produktif, memiliki komitmen dan kedisiplinan yang tinggi. Akan tetapi, mulai tahun 2013 -tepatnya semester genap tahun akademik 
2013/2014- UNY telah membuat kebijakan baru yang salah satunya adalah menghentikan beberapa insentif yang diberikan kepada dosen. Insentif yang dihilangkan tersebut, diantaranya adalah mengajar, membuat soal, mengawas ujian, dan mengoreksi hasil ujian.

Dari hasil penelitian ditemukan bahwa hadirnya kebijakan penghentian beberapa insentif tersebut, bagi sebagian pihak dinilai tidak memiliki pengaruh terhadap kinerja dosen, diantara mereka adalah para pengambil kebijakan baik yang ada di tingkat universitas maupun di tingkat fakultas, dan sedikit dosen. Sedangkan bagi pihak yang lain dinilai telah memiliki pengaruh terhadap penurunan dari kinerja dosen, khususnya dalam proses belajar mengajar, diantara mereka umumnya adalah para jajaran dosen.

Bagi para pengambil kebijakan, penghilangan beberapa insentif finansial dosen tersebut tidak mempengaruhi kinerja dosen, karena beberapa alasan. Alasan yang pertama, pengambil kebijakan berpendapat bahwa dosen telah mendapatkan tunjangan sertifikasi dosen (serdos) yang telah meng-cover semua insentif yang dihilangkan tersebut, bahkan jika diminta memilih, para dosen akan memilih mendapatkan serdos daripada mendapatkan beberapa insentif finansial tersebut. Karena jika dilihat dari segi waktu pendistribusiannya kepada dosen, beberapa insentif finansial yang dihilangkan tersebut diberikan pada saat akhir semester, sedangkan tunjangan serdos diberikan setiap bulan. Selain itu, jika dilihat dari segi besaran jumlah nominal insentif finansial yang dihilangkan tersebut, juga masih lebih besar tunjangan serdos.

Alasan berikutnya, kedua, adalah mengembalikan pada tupoksi dosen yang sebenarnya, yaitu mengajar sampai dengan mengeluarkan nilai. Alasan ketiga adalah antisipasi pengurangan dana yang diakibatkan dari adanya sistem UKT bagi mahasiswa baru tahun 2013/2014. Dengan adanya UKT, semua pengambil kebijakan sepakat bahwa UNY akan mengalami defisit anggaran atau mengalami kekurangan pada awal diberlakukannya sistem UKT tersebut.
Menurut pengambil kebijakan universitas ketiga alasan di atas telah dipahami secara baik oleh sebagian besar dosen di UNY setelah kebijakan ini berjalan. Sehingga sekali lagi menurut mereka, secara signifikan tidak banyak dosen yang meninggalkan tugasnya mengajar dan mengawas ujian hanya dikarenakan beberapa insentif tersebut dihilangkan.

Argumen di atas juga diamini oleh beberapa pengambil kebijakan di tingkat fakultas. Misalnya, pihak dekanat di Fakultas Ekonomi dan Fakultas Bahasa dan Seni yang menilai bahwa penghilangan beberapa insentif finansial dosen tersebut tidak mempengaruhi kinerja dosennya, bahkan menambah semangat para dosen untuk menjalankan tugasnya. Para dosen yang demikian ini, pada umumnya adalah dosen yang sudah menganggap bahwa tugas mengajar adalah sebagai aktualisasi diri. Bagi para dosen yang telah memiliki niat mengajar sebagai aktualisasi diri, memang menganggap bahwa insentif dalam bentuk finansial tidak begitu berpengaruh. Hal ini dikarenakan selain para dosen tersebut sudah mendapatkan serdos, tapi juga memiliki kegiatan atau profesi di luar dosen yang tentu memiliki income lebih. Misalnya, dosen-dosen di FE, dimana sebagian besar dari mereka memiliki income tambahan dari luar kampus, misalnya wirausaha, sebagai konsultan ekonomi, dan pemeriksa keuangan. Sedangkan dosen-dosen di FBS, sebagian besar dari mereka juga menjadi tenaga pengajar di P3B UNY dan pengajar di kelas-kelas internasional yang bekerja sama dengan beberapa negara, seperti China, Mosko, Polandia dan Thailand.

Pendapat para pengambil kebijakan seperti dijelaskan di atas berbeda dengan pendapat para dosen. Bagi sebagian besar dosen di UNY, khususnya yang belum mendapatkan serdos, penghilangan beberapa insentif finansial tersebut cukup berpengaruh terhadap kinerja mereka. Karena penghilangan insentif finansial ini mereka anggap sebagai penurunan income dan tentu berdampak pada keuangan pribadi do-sen. Pada akhirnya, hal ini juga mempengaruhi tingkat motivasi dan kinerja dosen di kelas. 
Argumen di atas sesuai dengan temuan penelitian yang menunjukkan bahwa para dosen lebih banyak memilih mengajar dengan jumlah sks minimal (mengajar 12 sks) setelah dihilangkannya insentif finansial untuk mengajar. Dampak dari sikap dosen tersebut adalah telah membuat para dosen yang memiliki tanggung jawab untuk menjadi koordinator mata kuliah universiter menjadi bemper untuk menghendel permintaan tugas mengajar mata kuliah universiter oleh semua fakultas di UNY.

Selain itu, pengaruh insentif juga terlihat dari semangat dosen mengajar dengan jumlah pertemuan 100 persen (16 kali pertemuan) saat insentif mengajar diberikan sebelum tahun 2013. Sehingga pada saat jumlah pertemuan tersebut kurang dari 16 kali pertemuan, maka seorang dosen akan mengusahakan untuk mengganti perkuliahan yang kosong. Berbeda pada saat insentif mengajar ini dihilangkan. Beberapa dosen sepakat bahwa mereka hanya mengajar minimalis (sesuai kebutuhan), yaitu 75 persen dari jumlah pertemuan yang ditentukan (12 kali pertemuan), dan tidak ada itikad untuk mengganti supaya jumlah pertemuan menjadi 100 persen. Bahkan beberapa dosen mengurangi jumlah jam dalam tiap pertemuan. Meskipun sikap tersebut hanya berdampak dari segi kuantitas suatu perkuliahan, akan tetapi tidak menutup kemungkinan juga akan mengurangi kualitas perkuliahan.

Selain menurunnya motivasi dosen dalam mengajar, temuan penelitian juga menunjukkan pengaruh penghilangan beberapa insentif terlihat pada menurunnya motivasi dosen untuk mengawas ujian secara langsung. Sehingga tugas mengawas ujian akhir semester ini biasanya dipercayakan kepada dosen piket atau karyawan.

\section{Simpulan dan Saran}

\section{Simpulan}

Pertama, UNY telah memberikan tiga macam insentif kepada para dosen yang mengajar di dalamnya, yakni: (a) insentif finansial, yang berbentuk direct incentives dan indirect incentives); (b) insentif nonfinansial; dan (c) insentif dalam katagori punishment (perverse incentives). Ketiga macam insentif untuk dosen ini, sebagian diberikan oleh pihak universitas dan sebagian yang lain diberikan oleh pihak fakultas kepada para dosen yang mengajar di UNY.

Kedua, insentif yang diberikan oleh UNY memiliki mekanisme pendistribusian dan pengelolaan yang berbeda. Insentif finansial dalam katagori direct incentives telah diatur dalam satu paket kebijakan universitas dalam bentuk Peraturan Rektor tentang Standar Umum Pembiayaan Universitas yang dilakukan perubahan setiap tahunnya disesuaikan dengan anggaran dan kebutuhan universitas. Adapun untuk insentif non-finansial dan insentif dalam katagori punishment diatur dalam satu aturan yang hidden rule. Sedangkan untuk insentif dosen yang diberikan oleh tiap-tiap fakultas yang ada di UNY, umumnya diatur secara partikular dalam sebuah SK tertentu berdasarkan kegiatan, baik insentif yang bersifat finansial, non-finansial maupun insentif hukuman (perverse incentives).

Pengelolaan dan pendistribusian insentif di UNY yang berbeda-beda dan diatur secara partikular tersebut, dikarenakan di UNY baik di tingkat universitas maupun fakultas tidak memiliki satu aturan khusus dan integral yang mengatur mekanisme pemberian insentif untuk dosen. Ketiadaan aturan yang secara khusus dan integral tersebut, dikarenakan oleh cara pandang pengambil kebijakan di UNY yang meletakkan insentif sebagai komponen yang bersifat "sunnah" (second priority) untuk diberikan pada dosen.

Ketiga, insentif yang diberikan oleh UNY kepada tenaga akademik memiliki dua tujuan utama, yaitu (a) memberikan tambahan dari segi ekonomi bagi seorang dosen khususnya terkait dengan insentif finansial; dan (b) memberikan stimulus agar dosen lebih memiliki kedisiplinan, tanggung jawab/komitmen, motivasi yang tinggi dan lebih produktif dalam menjalankan tugasnya sebagai dosen.

Keempat, penghentian beberapa insentif finansial untuk dosen disebabkan 
oleh antisipasi akan defisitnya anggaran akibat diterapkannya sistem UKT, dan bagian dari upaya mengembalikan pada tupoksi dosen yang sesungguhnya (back on the right track). Penghentian insentif finansial ini tidak mendapatkan penolakan dan protes dari pihak pejabat dekanat. Akan tetapi dijajaran dosen terdapat pihak-pihak yang menolak dan mengajukan protes, dan juga terdapat pihak-pihak yang menerima begitu saja.

Kelima, pengaruh insentif. Secara umum, insentif baik finansial maupun nonfinansial memiliki pengaruh terhadap kinerja dosen. Tetapi, insentif finansial memiliki pengaruh yang lebih terhadap kinerja dosen, khususnya yang belum mendapatkan serdos. Karena insentif finansial dirasa penting untuk membantu keuangan dosen, terlebih bagi dosen yang belum mendapatkan tunjangan serdos.

Oleh karena itu, dengan dihilangkannya beberapa insentif finansial mulai tahun 2013 sangat mempengaruhi kinerja dosen, yang tidak hanya bagi dosen yang belum tersertifikasi tapi juga bagi dosen yang sudah tersertifikasi. Hal ini terlihat dari menurunnya motivasi dosen untuk memenuhi tugas mereka dalam mengajar dan mengawas ujian. Selain itu, juga dapat dilihat dari rendahnya tingkat dosen yang mau mengajar sesuai dengan jumlah pertemuan yang ditentukan oleh tiap fakultas, yaitu 16 kalipertemuan, dan rendahnya kehadiran dosen untuk mengawas langsung ujian mahasiswa.

Saran

Dari hasil penelitian, dapat diajukan saran terhadap UNY serta terhadap rekomendasi bagi penelitian lanjutan sebagai berikut.

Bagi pihak universitas, hendaknya membuat satu aturan khusus tentang insentif baik finansial maupun non-finansial untuk dapat dijadikan sebagai pedoman bagi pihak fakultas dalam mendesain mekanisme insentif untuk tenaga akademik. Pihak universitas perlu membuat satu mekanisme pengawasan bagi kinerja dosen untuk mengetahui seberapa jauh efektivi- tas dari pemberian insentif terhadap peningkatan kualitas dosen dan kemajuan lembaga.

Saran berikutnya bagi penelitian lanjutan mengenai pengaruh struktur insentif terhadap peningkatan kualitas dosen dan prestasi mahasiswa di perguruan tinggi. Penelitian ini berguna untuk mengetahui lebih jauh terkait dengan output dan outcome dari insentif yang diberikan oleh perguruan tinggi kepada para dosen.

\section{Daftar Pustaka}

Chapman, D. W. \& Miric, S. L. (2009). Education quality in the midle east. International Review of Education. 55. Pp. 311-344 DOI 10.1007/s11159009-9132-5. Diambil dari http://www.tamamproject.org/do cumentation/forum/share_your_re sources/selection_post/education_ quality_in_the_middle_east.pdf pada 8 Maei 2014 jam 12:16 PM.

Creswell, J. W. (2009). Research design quantitative, qualitative, and mixed methods approaches (third edition). California: SAGE Publications.

Goodman, S.F. \& Lesley J.T. (2010). Teacher incentive pay and educational outcomes: evidence from the New York City bonus program. Hasil penelitian ini disampaikan pada the PEPG Conference Merit Pay: Will It Work? Is It Politically Viable? di Harvard Kennedy School Cambridge, Massachusetts pada 3-4 Juni. Diunduh dari http://www.hks.harvard.edu/pep g/MeritPayPapers/goodman_turne r_10-07.pdf pada tanggal 13 Juni 2013.

Lazear, E. P. (2003). Teacher incentives. Swedish Economic Policy 10, pp.179214

Levacic, R. (2009). Teacher incentives and performance: an application of principal agent-theory. Oxford Development Studies. Vol 37, No 1, March. Routledge 
Mizala, A. \& Pilar R. (2005). “Teachers' salary stucture and incentices in chile", dalam Emiliana Vegas (Ed). Incentive to Improve Teaching: Leasson From Latin America. Washington DC: The World Bank.

Pramudyo, A. (2010). Analisis faktor-faktor yang mempengaruhi kinerja dosen negeri diperkerjakan pada kopertis v yogyakarta. JBTI, Vol.1, No.1, Februari 2010.

Siagian, S.P. (2002). Kiat meningkatkan produktivitas kerja. Jakarta: PT Rineka Cipta

Siagian, S.P. (2004). Teori motivasi dan aplikasinya. Jakarta: PT. Rineka Cipta.
Stajkovic, A. D., \& Luthans, F. (2001). Differential Effects of Incentive Motivators on Work Performance. The Academy of Management Journal. ProQuest Vol. 44, No. 3 (Jun., 2001), pp. $580-590$

Sugiyono. (2012). Memahami penelitian kualitatif. Bandung: Alfabeta.

Vegas, E. \& Umansky, I. (2005). “Improving teaching and learning through effective incentives lessons from education reforms in latin america". Dalam Emiliada Vegas, Ed. (2005). Incentives to Improve Teaching Lessons from Latin America. Washington, DC.: World Bank. 